\title{
SERUM ANTI- MULLERIAN HORMONE IS A BETTER PREDICTOR OF OVARIAN RESERVE AT THE EARLY FOLLICULAR PHASE.
}

\author{
Ashraf Hany Abdel Rahman. MD.(1)\&(3), Samir Mohamed Elsaid(1) \\ and Hadeer Aly Abbassy. MD. ${ }^{(2)}$ \\ (1) Obstetrics \& Gynecology Dpt, Faculty of Medicine, Alexandria University. \\ ${ }^{(2)}$ Clinical and Chemical pathology Dpt, Alexandria University \\ (3) Madina infertility private center
}

\begin{abstract}
Objective : The study aim was to compare the relationship between serum anti-Müllerian hormone (AMH) levels and other markers of ovarian reserve and to determine its predictive value.

Design: prospective randomized trial .

Setting : Alexandria University and IVF-ICSI Madina private center.

Patients : 60 infertile women under going IVF-ICSI programmes.

Main Outcome Measure (s): Comparison of early follicular (day-3) serum AMH levels among women with less than five retrieved oocytes and five or more oocytes. Antral follicle count, mature oocyte count, age, basal follicle-stimulating hormone $(\mathrm{FSH})$, inhibin $\mathrm{B}$, estradiol $\left(\mathrm{E}_{2}\right)$, serum $\mathrm{E}_{2}$ levels at day of hCG, and pregnancy success were also compared.

Result (s): The mean serum AMH levels of patients with more than five retrieved oocytes were significantly higher $(0.67 \pm 0.41$ vs. $0.15 \pm 0.11 \mathrm{pg} / \mathrm{ml})$. Mature oocyte counts, antral follicle counts, and maximum $\mathrm{E}_{2}$ levels were found to be statistically significantly different in the two groups despite the homogeneity of ages and levels of basal FSH and $\mathrm{E}_{2}$. Conclusion(s): This suggests that AMH may reflect ovarian follicular status better than the usual hormone markers.
\end{abstract}

Key words: anti- müllerian hormone (AMH), ICSI.

\section{INTRODUCTION}

Anti-Müllerian hormone (AMH) is a glycoprotein hormone that belongs to the transforming growth factor superfamily (1) and is chiefly expressed in the fetal testis to drive differentiation of the mammalian reproductive tract $^{(2)}$. In women, granulosa cell production of $\mathrm{AMH}^{(3)}$ is barely detectable at birth (4) and reaches the highest values after puberty (5). During adulthood, although $\mathrm{AMH}$ continues to be expressed at basal and similar levels by both the Sertoli and granulosa cells ${ }^{(5)}$, its biological role is poorly understood.

Basic research data obtained from the adult ovary indicate that $\mathrm{AMH}$ is likely to be involved in the regulation of follicular steroidogenesis. Experiments conducted in animals suggest that $\mathrm{AMH}$ reduces aromatase activity and the number of LH receptors in FSH-stimulated granulosa cells ${ }^{(6)}$, and also influences testosterone production by theca cells ${ }^{(7)}$. In addition, growing evidence indicates that $\mathrm{AMH}$ is mainly expressed in pre-antral and carly antral follicles ${ }^{(8)}$. It has either direct or indirect roles in various phases of folliculogenesis, from the primordial $^{(9)}$ to FSH-sensitive ${ }^{(10,11)}$ follicular stages, probably via specific AMH type II receptors that are expressed in granulosa and theca cells. This suggests that, in contrast to other hormonal markers of ovarian function, AMH secretion might concurrently reflect the activity of pre-antral and early antral follicles, which makes it a promising parameter in the 
evaluation of ovarian follicular reserve.

Recent clinical evidence is in agreement with this hypothesis. One group ${ }^{(12)}$ demonstrated that serum AMH levels on cycle day 3 decrease progressively along with age and become undetectable after menopause. This suggests that peripheral AMH levels are a valuable parameter to monitor the relative follicular exhaustion due to ovarian ageing. Consistently, others ${ }^{(13)}$ showed that day $3 \mathrm{AMH}$ levels are positively related with the number of oocytes retrieved after controlled ovarian hyperstimulation ( $\mathrm{COH})$. Taken together, these results indicate that circulating AMH levels reflect the number of selectable follicles during the early follicular phase. Indeed, the early antral follicle count has been shown to reliably predict the fertility potential of women ${ }^{(14)}$ and their responsiveness to $\cos (15,16)$.

However, the question of whether serum AMH measurements carly in the follicular phase (on cycle day 3) reflect ovarian follicular status better than the usual hormonal parameters remains unanswered. Hence, the present investigation was planned to demonstrate the value of AMH as an indicator of ovarian reserve in comparison with other parameters of ovarian reserve (inhibin $\mathrm{B}$, estradiol $\left(\mathrm{E}_{2}\right), \mathrm{FSH}$ and LH carly in the follicular phase or on cycle day 3 ).

\section{MATERIALS \& METHODS}

\section{Subjects}

The study started in March 2007 by a total of 60 infertile women (age range $25-40$ years). In order to be included, the women had to meet the following criteria: (i) regular, ovulatory menstrual cycles every 25-35 days; (ii) both ovaries present; (iii) no current or past diseases affecting ovaries or gonadotrophin or sex steroid secretion, clearance or excretion; (iv) a body mass index (BMI) of $18-27 \mathrm{~kg} / \mathrm{m}^{2}$; (v) no current hormone therapy; and (vi) adequate visualization of ovaries at transvaginal ultrasound scanning. All patients were undergoing routine explorations before IVF - ICSI - embryo transfer. Informed consent was obtained from all women .

\section{Study protocol :}

On day 3 of the menstrual cycle, each woman underwent blood sampling by venipuncture for measurement of serum levels of AMH, inhibin $B, E_{2}$, FSH and LH at approximately 09:00 h. Later in the morning, ovarian ultrasound scanning was performed using a 4.5-7.2 $\mathrm{MHz}$ multi-frequency transvaginal probe (new sonic, USA) by one operator (R.F.), who was blinded to the results of the hormone assays.

Long-protocol GnRH analogue was used for menstrual suppression. On cycle day $21,0.5 \mathrm{mg} /$ day of subcutaneous Buserlin acetate, was begun; $E_{2}$ levels less than $50 \mathrm{pg} / \mathrm{mL}$ on cycle day 2 and endometrial thickness less than $4 \mathrm{~mm}$ indicated down-regulation. Treatment with recombinant FSH, 150-300 IU/day, was started. Patients with serum $E_{2}$ levels less than $100 \mathrm{pg} / \mathrm{mL}$ and follicle count less than 3 on cycle day 5 were submitted to step-up protocol. Step-up or step-down protocols were decided according to subsequent ultrasound controls. In cases of less than two growing follicles or a serum $E_{2}$ level of less than $300 \mathrm{pg} / \mathrm{mL}$ on cycle day 14 , treatment cycle was cancelled.

After more than three follicles larger than $18 \mathrm{~mm}$ were observed, 10,000 IU of hCG was administered intramuscularly, and 36 hours later follicles were aspirated under general anesthesia. Mature oocytes were retrieved from follicular fluid and placed in culture medium (G-1 TM version 3; Vitrolife, Goteborg, Sweden) prepared for ICSI and blastocyst development media (G-2 TM version 3; Vitrolife).

The study group was divided into two subgroups according to the number of oocytes retrieved. Patients with an oocyte count of five or more were considered good responders, and patients with less than five as poor responders. The 30 patients being treated for male factor infertility received ICSI; and IVF - ICSI 
was provided for the 23 patients with other infertility causes. In ten patients, cycles were cancelled for economic reasons. The transfer of the embryos was performed 48 to 72 hours after the procedure. Before transfer, the embryos were evaluated microscopically to ensure six to eight cells in each embryo of grades 1 to 2. A maximum of three embryos was transferred. On the 12 th to $14^{\text {th }}$ days of the transfer, a serum $\beta$-hCG test was performed to confirm pregnancy.

\section{Statistical analysis}

Statistical analysis were performed using the $\chi^{2}$, or t-test as appropriate. All P-value quoted with values $<0.05$ indicate statistical significance. Analysis were performed using the SPSS statistical package (SPSS, Inc, Chicago)

\section{Hormone measurements}

Serum was separated from all blood samples and frozen in aliquots at $-20^{\circ} \mathrm{C}$ until used for subsequent centralized analysis. Serum AMH levels were determined using an ultrasensitive enzyme-linked immunosorbent assay (ELISA) (Beckman-Coulter, Villepinte, France) as described previously (17). For AMH, functional sensitivity was $0.24 \mathrm{pg} / \mathrm{ml}$. Serum inhibin B levels were determined using a double antibody ELISA (Serotec, Varilhes, France) as described previously ${ }^{(18)}$. For inhibin B, functional sensitivity was $15 \mathrm{pg} / \mathrm{ml}$. Serum levels of $E_{2}, F S H$ and $\mathrm{LH}$ were determined using an automated multi-analysis system with chemiluminescence detection (ACS-180; Bayer Diagnostics, Puteaux, France). For $E_{2}$, functional sensitivity was $15 \mathrm{pg} / \mathrm{ml}$. For FSH and LH, functional sensitivity was 0.1 $\mathrm{mIU} / \mathrm{ml}$.

\section{RESULTS}

The study included 60 patients in the IVF-ICSI program. Ten patients dropped out of the study for economic reasons. Six patients' AMH levels could not be determined for technical reasons. Of the remaining 44 couples, the causes of infertility were male factor ( 25 couples), tubal factor (seven couples), and idiopathic (12 couples). The ages of the female patients were between 24 and 39 years. The mean infertility period was $9 \pm 3.9$ years, and the mean body mass index of female patients was in the normal range (see Table). Ovarian reserve was assessed by basal hormone levels on cycle day 3 .

Treatment was started with a mean dose of $244 \pm$ 59 IU/day of recombinant FSH (150-300 IU); a total dose of $2410 \pm 978$ IU/day (1050-5400 IU) was reached. A mean period of $9 \pm 2$ days (5-14) was spent on the treatment. The results of the study were evaluated according to the number of growing follicles, oocytes, and mature oocytes retrieved (see Table I). Fifteen couples ended in pregnancy. Two of them continued as twin pregnancies, and cight as singletons. Three pregnancies were aborted, and two were biochemical pregnancies.

The study group was divided into two subgroups according to the number of oocytes retrieved. Patients with an oocyte count of five or more were considered good responders and less than five as poor responders. All parameters were compared for these two groups. Characteristics such as age, infertility period, and body mass index were similar between good and poor responders.

Good responders had a mean beginning dose of $249 \pm 58 \mathrm{IU} /$ day, and a total dose of $2363 \pm 969 \mathrm{IU}$ was reached in $8 \pm 2$ days. Poor responders had a mean starting dose of $231 \pm 62 \mathrm{IU} /$ day, and a total dose of $2550 \pm 1041$ IU was reached in a mean period of $9 \pm 1$ days. These parameters were statistically alike. Parameters such as basal scrum FSH, inhibin B and E2 levels were also not statistically different. Meanwhile, the difference between serum AMH levels, maximum E2 levels, antral follicle count, hCG day follicle counts, and mature oocyte counts were statistically significant (see Table I).

The main parameter of the study, $\mathrm{AMH}$, was found to be considerably higher in good responders; mean level was $0.67 \pm 0.41 \mathrm{pg} / \mathrm{mL}$. The AMH level was $0.15 \pm 0.11 \mathrm{pg} / \mathrm{mL}$ in poor responders $(\mathrm{P}<.001)$. 
Table I:

\begin{tabular}{|l|c|c|c|}
\hline \multicolumn{1}{|c|}{ Parameters } & $\begin{array}{c}\text { Poor responders } \\
\mathbf{n = 1 1}\end{array}$ & $\begin{array}{c}\text { Good responders } \\
\mathbf{n}=33\end{array}$ & P value \\
\hline Agc & $32.63 \pm 3.58$ & $30.75 \pm 4.10$ & NS \\
\hline Infertility period & $12.0 \pm 4.17$ & $8.0 \pm 3.37$ & NS \\
\hline Body mass index & $24.68 \pm 5.14$ & $24.69 \pm 2.94$ & NS \\
\hline Day-3FSH (mIu/ml) & $7.35 \pm 3.49$ & $7.53 \pm 2.23$ & NS \\
\hline Day-3 E2 (pg/ml) & $36.40 \pm 22.86$ & $33.16 \pm 9.83$ & NS \\
\hline Day-3LH (mlu/ml) & $8.44 \pm 11.17$ & $5.40 \pm 2.58$ & NS \\
\hline Day-3 AMH (pg/ml) & $0.15 \pm 0.11$ & $0.67 \pm 0.41$ & $\mathrm{P}<0.001$ \\
\hline Day 3 Inhibine B( pg/ml) & $16 \pm 182$ & $18 \pm 174$ & $\mathrm{NS}$ \\
\hline Antral follicle count & $6.90 \pm 3.41$ & $10.63 \pm 3.89$ & $\mathrm{P}<0.001$ \\
\hline hCG day E2 (pg/ml) & $1252.54 \pm 605.29$ & $2584.81 \pm 927.02$ & $\mathrm{P}<0.001$ \\
\hline Follicle count & $6.09 \pm 2.42$ & $11.66 \pm 3.01$ & $\mathrm{P}<0.001$ \\
\hline Retrieved oocyte count & $3.54 \pm 1.21$ & $10.69 \pm 3.47$ & $\mathrm{P}<0.001$ \\
\hline Mature oocyte count & $2.6 \pm 1.2$ & $9.21 \pm 3.68$ & $\mathrm{P}<0.001$ \\
\hline
\end{tabular}

\section{DISCUSSION}

The present investigation was designed to evaluate the direct relationship between peripheral AMH levels, measured by an ultrasensitive ELISA technique, and the ovarian follicular status on cycle day 3.

Our data demonstrate an association between early follicular phase serum AMH and number of retrieved oocytes despitc clinically similar day-3 serum FSH and $E_{2}$ levels in patients of all age groups. Baseline $\mathrm{FSH}, \mathrm{LH}$, inhibin $\mathrm{B}$ and $\mathrm{E}_{2}$ levels are good predictors of ovarian reserve $(19,20)$. As noted by other studies, Jurema et al. ${ }^{(21)}$ found that levels of baseline FSH and $E_{2}$ but not $\mathrm{LH}$ were statistically significantly lower in cycles resulting in a normal ovarian response as well as cycles resulting in clinical pregnancy. It was also stated that a stricter FSH value ( $8 \mathrm{IU} / \mathrm{mL})$ would have been required for the group of patients with poor prognosis ${ }^{(19,20,21)}$. In our study, good and poor responder groups had similar mean baseline FSH levels (lower than 8 $\mathrm{IU} / \mathrm{mL}$ ), which gave us an opportunity to underline the importance of $\mathrm{AMH}$ and the relation between $\mathrm{AMH}$ and the number of retrieved oocytes.

Bancsi et al. ${ }^{(22)}$ found that antral follicle count is the best single indicator for ovarian response. The combination of antral follicle count with basal FSH and inhibin B levels improved prediction. Van Rooij et al. ${ }^{(23)}$ combined antral follicle count with AMH and inhibin $\mathrm{B}$ to provide for better prediction. Fanchin et al. ${ }^{(24)}$ found that AMH levels correlated more with the number of early antral follicles than did inhibin $\mathrm{B}, \mathrm{E}_{2}, \mathrm{FSH}$, or $\mathrm{LH}$ on cycle day 3 .

Expression of AMH begins in the third trimester of gestation, long before it can be detected in serum. As a result, it is thought to play an important role in early follicular development. Once menstrual cycles begin, serum AMH levels fluctuate slightly from baseline due to the stimulation of a small cohort of follicles and loss of AMH production from corpus luteum ${ }^{(25,26)}$. Our results demonstrated an association among AMH and antral follicles and retrieved oocyte count; so serum AMH levels may reflect the size of antral follicle pool. It may thus provide a marker associated with the anticipated 
number of oocytes to be retrieved after controlled ovarian stimulation. Early follicular phase AMH levels result from the pool of follicles that began producing it in utero, and this production is independent of the gonadotropin-dependent indicators of ovarian reserve; this makes AMH unique in providing a perspective not available by using current serum markers and ultrasound ${ }^{(13)}$.

Thus, basal antral follicle count and basal AMH levels are good tools for use in counseling patients ${ }^{(27-13,22,24)}$. However, accurate antral follicle counts depend on the clinician's experience and the technical properties of the ultrasound used. By contrast, AMH levels are obtained by objective measurements performed in laboratory medium and thus are free of interobserver variability and personal comments.

\section{CONCLUSIONS}

our data indicate that early follicular AMH levels can offer a contribution to the serum markers currently being used for evaluating ovarian reserve, but $\mathrm{AMH}$ levels will not reveal the possibility of pregnancy.

\section{REFERENCES}

1. Pepinsky, R.B., Sinclair, L.K., Chow, E.P., Mattaliano, R.J., Manganaro, T.F., Donahoe, P.K. and Cate, R.L. Proteolytic processing of Mullerian inhibiting substance produces a transforming growth factor- -like fragment. J. Biol. Che 1988; 263, 18961-18964.

2. Lee, M.M. and Donahoe, P.K. Mullerian inhibiting substance: a gonadal hormone with multiple functions. Endocr. Rev 1993; 14, 152-164.

3. Vigier, B., Picard, J.Y., Tran, D., Legeai, L. and Josso, N. Production of anti-Müllerian hormone: another homology between Sertoli and granulosa cells. Endocrinology 1984; 114, 1315-1320.

4. Rajpert-De Meyts, E., Jorgensen, N., Graem, N., Muller, J., Cate, R.L. and Skakkebaek, N.E. Expression of anti-Mullerian hormone during normal and pathological gonadal development: association with differentiation of Sertoli and granulosa cells. J. Clin. Endocrinol. Metab 1999; 84, 3836-3844.

5. Hudson, P.L., Dougas, I., Donahoe, P.K., Cate, R.L.. Epstein, J., Pepinsky, R.B. and MacLaughlin, D.T. An immunoassay to detect human mullerian inhibiting substance in males and females during normal development. J. Clin. Endocrinol. Metab $1990 ; 70,16-22$

6. Josso, N., Racine, C., di Clemente, N., Rey, R. and Xavier, F. The role of anti-Mullerian hormone in gonadal development. Mol. Cell. Endocrinol 1998; 145, 3-7.

7. Ingraham. H.A., Hirokawa, Y., Roberts, L.M., Mellon, S.H., McGee, E., Nachtigal, M.W. and Visser, J.A. Autocrine and paracrine Mullerian inhibiting substance hormone signaling in reproduction. Recent Prog. Horm. Res 2000;55, 53-67.

8. Baarends, W.M., Uilenbroek, J.T., Kramer, P., Hoogerbrugge, J.W., van Leeuwen, E.C., Themmen, A.P. and Grootegoed, J.A. Anti-mullerian hormone and anti-mullerian hormone type II receptor messenger ribonucleic acid expression in rat ovaries during postnatal development, the estrous cycle, and gonadotropin-induced follicle growth. Endocrinology $1995 ; 136,4951-4562$.

9. Durlinger, A.L., Gruijters, M.J., Kramer, P., Karels, B., Ingraham, H.A., Nachtigal, M.W., Uilenbroek, J.T., Grootegoed, J.A. and Themmen, A.P. Anti-Mullerian hormone inhibits initiation of primordial follicle growth in the mouse ovary. Endocrinology 2002; 143, 1076-1084.

10. Durlinger, A.L., Gruijters, M.J., Kramer, P., Karels, B., Kumar, T.R., Matzuk, M.M., Rose, U.M., de Jong, F.H., Uilenbroek, J.T., Grootegoed, J.A. and Themmen, A.P. Anti-Mullerian hormone attenuates the effects of FSH on follicle development in the mouse ovary. Endocrinology 2001; 142, 4891-4899.

11. McGee, E.A., Smith, R., Spears, N., Nachtigal, M.W., Ingraham, H. and Hsuch, A.J. Mullerian inhibitory substance induces growth of rat preantral ovarian follicles. Biol. Reprod 200; 64, 293-298.

12. De Vet, A., Laven, J.S., de Jong, F.H., Themmen, A.P. and Fauser, B.C. Antimullerian hormone serum levels: a putative marker for ovarian aging. Fertil. Steril 2002; 77, 357-362.

13. Seifer, D.B., MacLaughlin, D.T., Christian, B.P., Feng, B. and Shelden, R.M. Early follicular serum 
mullerian-inhibiting substance levels are associated with ovarian response during assisted reproductive technology cycles. Fertil. Steril 2002; 77, 468-471.

14. Reuss, M.L., Kline, J., Santos, R., Levin, B. and Timor-Tritsch, I. Age and the ovarian follicle pool assessed with transvaginal uJtrasonography. Am. J. Obstet. Gynecol 1996; 174, 624-627.

15. Chang, M.Y., Chiang, C.H., Hsieh, T.T., Soong, Y.K. and Hsu, K.H. Use of the antral follicle count to predict the outcome of assisted reproductive technologies. Fertil. Steril 1998; 69, 505-510.

16. Lász]6, F.J.M.M., Bancsi, L.F., Broekmans, F.J., Eijkemans, M.J., de Jong, P.H., Habbema, J.D. and te Velde, E.R. Predictors of poor ovarian response in in vitro fertilization: a prospective study comparing basal markers of ovarian reserve. Fertil. Steril 2002; 77, 328-336

17. Long, W.Q., Ranchin, V., Pautie, P., Belville, C., Denizot, P., Cailla, H., Lhomme, C., Picard, J.Y., Bidart, J.M. and Rey, R. Detection of minimal levels of serum anti-Mutlerian hormone during follow-up of patients with ovarian granulosa cell tumor by means of a highly sensitive enzyme-linked immunosorbent assay. J. Clin. Endocrinol. Metab $2000 ; 85,540-544$.

18.Groome, N.P., Illingworth, P.J., O'Brien, M., Pai, R., Rodger, F,E., Mather, J.P. and MeNejlly, A.S. Measurement of dimeric inhibin B throughout the human menstrual cycle. J. Clin. Endocrinol. Metab 1996; 81, 1401-1405.

19.Bukulmez O, Arici A. Assessment of ovarian reserve. Curr Opin Obstet Gynecol 2004; 16:231-237.

20.Kwee J, Elting MW, Schats R, Bezemer PD, Lambalk $\mathrm{CB}$, Schoemaker J. Comparison of endocrine tests with respect to their predictive value on the outcome of ovarian hyperstimulation in IVF treatment: results of a prospective randomized study. Hum Reprod 2003;18:1422-1427.

21.Jurema MW, Bracero NJ, Garcia JE. Fine tuning cycle day 3 hormonal assessment of ovarian reserve improves in vitro fertilization outcome in gonadotropin-releasing hormone antagonist cycles. Fertil Steril 2003; 80:1156-1161.

22.Bancsi LF, Broekmans FJ, Eijkemans MJ, de Jong FH, Habbema JD, te Velde ER. Predictors of poor ovarian response in in vitro fertilization: a prospective study comparing basal markers of ovarian reserve. Fertjl Steril 2002; 77: 328-336.

23.Van Rooij IA, Broekmans FJ, te Velde ER, Bancsi LF, de Jong FH, Themmen AP. Serum antimüllerian hormone Ievels: a novel measure of ovarian reserve. Hum Reprod 2002; 17 : 3065-3071.

24.Fanchin $R$, Schonauer LM, Righini $C$, Guibourdenche J, Frydman R, Taieb J. Serum anti-Müllerian hormone is more strongly related to ovarian follicular status than serum inhibin $B$, estradiol, FSH and LH on day 3. Hum Reprod 2003; 18: 323-327.

25.Cook CL, Siow Y, Taylor S, Fallat ME. Serum mîllerian inhibiting substance levels during normal menstrual cycles. Fertil Steril 2000;73: 859-861.

26.De Vet A, Laven JS, de Jong FH, Themmen AP, Fauser BC. Antimüllerian hormone serum levels: a putative marker for ovarian aging. Fertil Steril 2002; 77: 357-362.

27.Laven JS, Mulders AG, Visser JA, Themmen AP, De Jong FH, Fauser BCJM. Antimüilerian hormone serum concentrations in normoovulatory and anovulatory women of reproductive age. $\mathrm{J} \mathrm{Clin}$ Endocrinol Metab 2004; 89: 318-323. 